\title{
Chorionic gonadotrophin and embryo-maternal recognition during the peri-implantation period in primates
}

\author{
J. P. Hearn ${ }^{1,2}$, G. E. Webley ${ }^{2}$ and A. A. Gidley-Baird ${ }^{3}$ \\ ${ }^{1}$ Wisconsin Regional Primate Research Center, University of Wisconsin, Madison, WI 53715, USA, \\ ${ }^{2}$ Institute of Zoology, Regent's Park, London, NWI 4RY, UK; and ${ }^{3}$ Department of Veterinary \\ Physiology, University of Sydney, NSW 2006, Australia
}

\begin{abstract}
Summary. Genes for chorionic gonadotrophin (CG) are transcribed by the 16-cell embryo stage in humans, but there is no clear evidence of $\mathrm{CG}$ secretion as a bioactive dimer before attachment and trophoblast outgrowth stages of implantation. The studies summarized question the timing of $\mathrm{CG}$ expression and secretion, the possible roles of $\mathrm{CG}$ for intraembryonic differentiation and at the implantation site, and the recognition of this primate embryo-derived signal in support of the corpus luteum. The data suggest that the implantation window in primates may be broader than in nonprimate species, where a closer synchrony between embryonic, tubal and uterine events appears to be necessary for embryonic survival. Some preliminary data concerning an association between peripheral thrombocytopenia, ovarian inhibin secretion and periimplantation stages of embryo development indicate that an unknown embryonic signal may be secreted before bioactive $\mathrm{CG}$ can be detected.
\end{abstract}

Keywords: chorionic gonadotrophin; corpus luteum; embryo; implantation; platelet-activating factor; inhibin; pregnancy; primate

\section{Introduction}

In all primate species studied, the embryo enters the uterus as a morula on Day 3-4 after ovulation, hatches from the zona pellucida on Days 6-8 and attaches to the endometrium on $\sim$ Days 7-9 (Old World species) or 11-12 (New World species). Implantation is highly invasive and interstitial in man and the apes, but relatively superficial in monkeys (simians) Hertig \& Rock, 1945; Hendrickx \& Enders, 1980; Enders et al., 1983; Moore et al., 1985; Hearn \& Summers, 1986; Smith et al., 1987; Hearn et al., 1988a, b, in press; Enders, 1989). Therefore, the morphology of implantation is now relatively well described for a few primate species, showing a similar general pattern, albeit with distinct species differences (Hearn, 1986).

The regulation of implantation, monitored through endocrine changes in peripheral plasma, is well studied as is the function of the corpus luteum (Knobil, 1973; Ross, 1979; Auletta \& Flint, 1988; Anderson \& Hodgen, 1989; Stouffer et al., 1989). There is a clear primate pattern with distinct species variations in timing and endocrine synchrony. Many questions remain to be answered concerning the timing of corpus luteum (CL) 'rescue' (Short, 1969, 1979), the extent of embryonic loss (Lenton et al., 1988), the regulation of receptor function, the autocrine or paracrine functions of oestrogens and progestagens in trophoblast or luteal tissues (Stouffer et al., 1989) and the dependence of the CL on embryo-derived gonadotrophin.

In contrast, there is little knowledge of the cellular and molecular processes regulating the activation and sequential expression of genes controlling embryonic signals, the attachment of the embryo to the endometrial epithelium, the rapid invasion of trophoblast, the establishment of embryo-maternal vascular links and the initial maternal responses to implantation by the endometrium. For example, the genes for chorionic gonadotrophin (CG) are thought to be expressed 
only in primates, but the ontogeny of their expression is unknown, as is the possible role of this hormone in local interactions at the implantation site. Equid CG is now thought to be similar to equid $\mathbf{L H}$, and the $\mathrm{C}$ terminal extensions of the $\beta$ subunit in primates and humans arose independently (Leigh \& Stewart, 1990). The difficulties in obtaining precise data on the genetic or biochemical processes at the embryo-maternal interface have been due to the scarcity of precisely timed material during a dynamic and rapidly changing series of events, the lack of suitable reagents and, in man, the ethical constraints at tached to such studies. While preimplantation development is now well described through advances in human in-vitro fertilization (Edwards, 1985), implantation in primates has yet to be studied in detail. Nevertheless, it is known from many studies of nonprimates that essential factors regulating implantation, endometrial receptivity and CL function in early pregnancy are distinct in primates from those in nonprimate species.

A greater understanding of these factors would advance our understanding of primate implantation and would be relevant to the treatment of infertility, the regulation of fertility, the explanation of early embryonic loss and the improvement of reproductive and embryonic health. Recent progress in this field is reviewed in a volume edited by Yoshinaga \& Mori (1989).

We examine here the timing of activation of the embryonic genome, explore the presence of putative preimplantation embryonic signals, test the hypothesis that chorionic gonadotrophin is the dominant embryonic signal required for the initiation of implantation and note other factors likely to be important during the establishment of embryo-maternal communication.

\section{Activation of the embryonic genome}

Early embryonic development is controlled by proteins coded for by two genomic sources: the products of the oocyte genome (maternal) and the transcription products of the embryonic genome proper. Cytoplasmic factors inherited from the oocyte control certain early differentiative events to the blastocyst stage (Tesarik, 1989). It is now apparent (Surani et al., 1990) that neither the male nor the female genome by itself is totipotential. Surani et al. (1990) propose that maternal chromosomes are required while embryonic cells are totipotential or pluripotential, but paternal cells may be needed for the proliferation of progenitor cells of differentiated tissues. Epigenetic modifications such as DNA methylation can modulate or balance functional differences on parental chromosomes.

At later stages of preimplantation embryo development, the time of establishment of trophoblast cell lineage specific gene expression is not known. Clarification of the earliest time of onset of embryonic genome activation (Table 1) is the first step in identifying and characterizing embryospecific signals and the ontogeny of their expression.

Table 1. Activation of the embryonic genome in mammals

\begin{tabular}{|c|c|c|}
\hline Species & Stage & Reference \\
\hline Mouse & 2-cell & $\begin{array}{l}\text { Flach et al. (1982) } \\
\text { Bolton et al. (1984) }\end{array}$ \\
\hline Rabbit & 8-cell & Manes (1973) \\
\hline Sheep & 8-cell & Crosby et al. (1988) \\
\hline Cow & $8-16$ cell & Frei et al. (1989) \\
\hline Hu Man & $\begin{array}{l}4-8 \text { cell } \\
6-8 \text { cell }\end{array}$ & $\begin{array}{l}\text { Braude et al. (1988) } \\
\text { Bonduelle et al }(1988)\end{array}$ \\
\hline
\end{tabular}

The presence of the $\beta$-subunit of CG was detected in 3 of seven $6-8$ cell human embryos by in-situ hybridization (Bonduelle et al., 1988). Although these were triploid embryos and their normality may be in doubt, this preimplantation transcription and expression of $C G$ raises questions 
about its cell-specific expression. There was equal expression among blastomeres, so lineage specificity cannot be established and trophectoderm lineage has yet to be established at this stage. Ohlsson et al. (1989) showed the expression of $\mathrm{CG} \alpha$ and $\beta$ subunits in the trophectoderm of the preimplantation embryo, but $\mathrm{CG} \beta$ has yet to be demonstrated in villous cytotrophoblasts. $\mathrm{CG}$ in the preimplantation embryo could not be syncytial in origin before the late blastocyst state (Enders, 1989), but, after the mature chorionic villi have formed, CG expression is restricted to the syncytiotrophoblast. The co-ordinated expression of both subunits for the secretion of biologically active $\mathrm{CG}$, together with the timing of such secretion and its physiological role within the embryo, at the embryo-endometrial interface or in trophoblast penetration, have yet to be clarified.

\section{Preimplantation embryonic signals}

There is no lack of candidates for embryo-derived signals during preimplantation stages of pregnancy. They include early pregnancy factor (Morton et al., 1977), platelet-activating factor (O'Neill, 1985), Schwangershaftsprotein (Sinosich et al., 1985), histamine-releasing factor (Cocchiara et al., 1987) and chorionic gonadotrophin. For a summary of such signals in nonprimate species, see Heap et al., 1988. With the exception of CG, the robustness of assays and the specificity of reagents available leave doubts as to the precise timing, involvement and physiological function of these putative signals. There are many descriptive studies that await experimental testing and confirmation of their biological functions.

We examined the transient thrombocytopenia reported to be associated with preimplantation stages in mouse and man (O'Neill, 1985). In studies of conception cycles in 10 marmoset monkeys with 6 nonpregnant controls, a transient thrombocytopenia of 15-30\% was found in the circulating platelets during preimplantation stages of pregnancy to Day 8 after ovulation in 7 animals, at which stage the embryos were flushed from the uteri to confirm their presence (Hearn et al., 1988b). We also studied the effects of culture media, from either 5 individual preimplantation or 4 postattachment embryos in vitro, injecting $(0.1 \mathrm{ml}$ aliquots) into splenectomized mice using the bioassay system developed by O'Neill (1985). A 15-30\% reduction in circulating platelets resulted over the subsequent $12 \mathrm{~h}$ from all 5 preimplantation embryo cultures and from 3 of the 4 postattachment stages sampled, whereas 5 controls with culture fluid only showed no effects (Table 2). This work supports the hypothesis of O'Neill (1985) that an embryo-derived preimplantation signal, perhaps platelet-activating factor is associated with the preimplantation phase of embryonic development. In contrast to the results in mice (O'Neill, 1985), in which the effect ceased to be detectable in peripheral plasma after implantation in vivo, perhaps because of neutralization by maternal factors, our preliminary studies of post-attachment embryos in vitro showed a maintenance of the effect when maternal influences were removed. More robust assays are required.

Platelet-activating factors (PAF) are potent inducers of vascular permeability. It is not known whether the embryo during the peri-implantation period is a direct source of PAF, or an indirect stimulus in its release. The function of PAF during oviducal or uterine stages of early embryonic development is also uncertain, but a recent report showed that PAF in the uterine stroma is released by the presence of a blastocyst in rabbits. Studies of cultured human luteal-phase endometrial, glandular epithelium and stromal cells showed low concentrations of PAF in normal cells; addition of oestradiol-17 $\beta$ to the cultures had no effect on these concentrations, but oestradiol and progesterone increased PAF concentrations in a dose-dependent manner, indicating hormonal regulation of the stromal cell content of PAF (Harper et al., 1989). Potentially relevant to this interaction are the studies of Wang et al. (1989) using anti-idiotype of monoclonal antiprogesterone antibody in the mouse uterus before implantation, showing that antiprogesterone antibody binds to an antigen associated with luminal and glandular epithelia, which may locally inhibit the uterine uptake of progesterone and disrupt implantation.

In Rhesus monkeys (Marston et al., 1977), marmoset monkeys (Summers et al., 1987) and in some human in-vitro fertilization practice, embryos at early tubal stages of development can be 
Table 2. Effects of injecting $0.1 \mathrm{ml}$ aliquots of media from individual cultures of morula to blastocyst or trophoblast to yolk sac stages of marmoset embryos in vitro on the circulating concentration of platelets measured in blood samples drawn from the orbital sinus of splenectomized, Quackenbush mice, using the methods of O'Neill (1985); reductions of $>15 \%$ were considered significant

\begin{tabular}{lcccc}
\hline Culture fluid & $n$ & \multicolumn{3}{c}{ Platelet reduction } \\
\hline $\begin{array}{c}\text { Fluid only } \\
\text { (controls) }\end{array}$ & 5 & 0 & 1 & 4 \\
$\begin{array}{c}\text { Morula to } \\
\text { blastocyst }\end{array}$ & 4 & 3 & 1 & 0 \\
$\begin{array}{c}\text { Trophoblast } \\
\text { to yolk sac }\end{array}$ & 5 & 5 & 0 & 0 \\
\hline
\end{tabular}

transferred to the uterus, thereby missing the 3-4 days they would normally spend in the oviduct and yet result in successful births, suggesting that the tubal location itself is redundant as a prerequisite in the establishment of implantation. Based on such results, the hypothesis may be posed that the tubal location is not essential for embryonic maturation, that any putative early embryonic signals at these stages are not essential for embryonic survival (unless they are carried through tubal fluids to the uterus) and that the uterus is capable of duplicating any tubal influences that are required. In contrast to nonprimate species, in which the close synchrony of embryo and uterine developments is critical for embryo survival (Moor et al., 1966; Finn, 1986), there may be greater flexibility in primate peri-implantation development and therefore a wider window of implantation than in nonprimates. Although a period in the Fallopian tube is not mandatory, there may, of course, be facilitatory effects that increase embryo survival.

The present uncertainties in our understanding of preimplantation embryonic signals, their timing and significance during the peri-implantation process and their physiological function in the establishment of embryo-maternal communication should be clarified in the next few years, with the ability to probe the implantation site through in-situ hybridization and amplification by polymerase chain reactions. The array of trophoblastic and endometrial factors activated through this short period and their structural consequences (e.g. Glasser et al., 1987; Waites \& Bell, 1989) require carefully timed peri-implantation material to be available through the sequential stages of embryo-maternal attachment and trophoblastic invasion. For primates this presents a challenge due to the scarcity of material, but one that may be met now that analyses can be carried out in single-embryo preparations.

Table 3. Estimated day, after ovulation, of embryo attachment to uterine endometrial epithelium in vivo and the day of first measurement of chorionic gonadotrophin (CG) in peripheral plasma, in five primate species

\begin{tabular}{lcrl}
\hline Species & $\begin{array}{c}\text { Embryo } \\
\text { attachment } \\
\text { (Day) }\end{array}$ & $\begin{array}{r}\text { CG first } \\
\text { detected } \\
\text { (Day) }\end{array}$ & \multicolumn{1}{c}{ Reference } \\
\hline Man & $7-9$ & $9-12$ & Lenton \& Woodward (1988) \\
Chimpanzee & $7-9 ?$ & $10-11$ & $\begin{array}{l}\text { Reyes } \text { et al. (1975) } \\
\text { Rhesus }\end{array}$ \\
Baboon & $8-10$ & $11-12$ & Shaikh (1978) \\
Marmoset & $11-12$ & $11-12$ & Atkinson et al. (1975) \\
\hline
\end{tabular}




\section{Implantation signals}

The first, and as yet only, clear embryonic marker or signal at implantation is chorionic gonadotrophin, which appears in the peripheral circulation of primates 2-3 days after embryonic attachment (Table 3). The genes for chorionic gonadotrophin, which in man is essentially an analogue of luteinizing hormone $(\mathrm{LH})$ with $\sim 30$ amino acid residues added at the $\mathrm{C}$-terminus of the $\beta$ subunit (Canfield et al., 1971), are thought to be present only in primates, where their normal expression is restricted to pregnancy, but abnormally may occur in various cancerous, and perhaps other tissues. The ontogeny of gene activation in embryo and trophoblast is now being clarified, with the singlegene-regulated $\alpha$ subunit and the $7 \beta$-subunit genes, only 3 of which are expressed in the placenta (Talmadge et al., 1984), now being cloned in some primate species. The first external secretion of $\mathrm{CG}$ by the human embryo is probably in the late blastocyst stages (Fishel et al., 1984; Hay \& Lopata, 1988), but our studies have not found biologically active CG secretion to be detectable in marmoset embryo culture fluids until the attachment of the blastocyst and initial spreading of trophoblast (Hearn et al., 1988a, b). Let us examine the production and inhibition of CG in vivo and in vitro and the consequences for implantation and early pregnancy in marmoset monkeys. Let us propose (in what is almost certainly a gross oversimplification) the hypothesis that, in primates, $\mathrm{CG}$ is the dominant embryo-secreted signal required for the initial stages of embryo recognition, attachment and the prolongation of CL function.

Table 4. Estimated day, after ovulation, when $\mathrm{CG}$ was first detected in the peripheral plasma of marmoset monkeys during 20 conception cycles in vivo, compared with the estimated day after ovulation of first measurement of CG in the media of 20 marmoset embryos cultured in vitro from morula-blastocyst stages through attachment to a monolayer of marmoset fibroblasts

\begin{tabular}{lccccc}
\hline \multicolumn{5}{c}{ First measurement of CG } \\
\hline $\begin{array}{l}\text { Days after ovulation } \\
\text { In vivo }(n=20)\end{array}$ & $8-9$ & $10-11$ & $12-13$ & $14-15$ & $16-18$ \\
In vitro $(n=20)$ & 0 & 0 & 1 & 8 & 11 \\
\hline Data are pooled from two studies using a radioimmunoassay (Chambers \& \\
Hearn, 1979) and a bioassay (Hearn et al., 1988a) for marmoset CG. \\
Detection using RIA was 1-2 days before that for bioassay. First \\
measurement in vitro was after attachment of embryos to the monolayer \\
and the initiation of trophoblast outgrowth (Hearn $e t$ al., 1988b).
\end{tabular}

Table 4 summarizes the first detectable secretion of $C G$ in vivo in 20 conception cycles dated from the day of ovulation, Days 14-18 being the norm and suggesting at least a 4-day 'implantation window'. Variable rates of development of marmoset embryos were found when they were flushed from uteri on each day of precisely timed conception cycles (Summers et al., 1987), which showed implantation in this primate to commence on Day 11-12. Therefore, CG can be detected in the peripheral circulation 2-3 days after embryo attachment in vivo.

In the more controlled conditions of in-vitro studies, the first detectable secretion of CG in embryo cultures of 20 marmoset embryos, recovered as blastocysts on Day 8 after ovulation and cultured individually on marmoset fibroblast feeder cell monolayers for the next 10 days, are centred on the day of blastocyst hatching, but again there was at least a 4-day period when embryos could attach and begin trophoblastic outgrowth (Table 4). All of these embryos showed secretion of CG immediately after attachment (Fig. 1), but CG using our bioassay system (Hearn et al., 1988a) was not detectable in culture media before the day of attachment and the initiation of 
trophoblastic outgrowth. With the availability of improved reagent specificity, we are now examining, first, the hatched blastocyst and then, in reverse sequence, the earlier stages, to probe for the location, expression sites and secretion of CG in the preimplantation embryo.

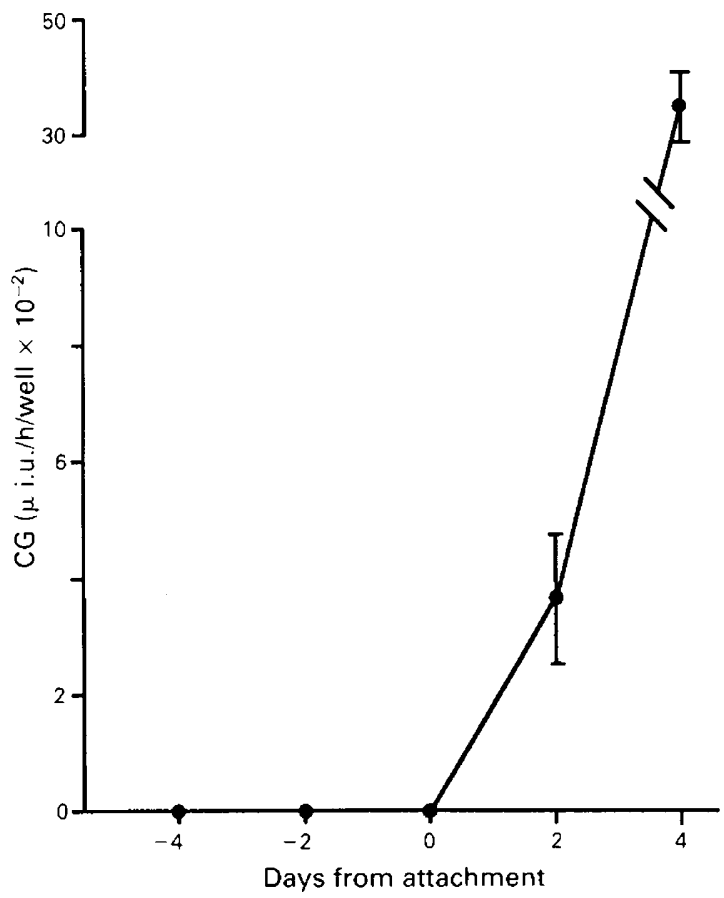

Fig. 1. Concentrations of biologically active chorionic gonadotrophin (CG), measured by mouse Leydig cell bioassay (Hearn et al., 1988a) in samples collected daily from 20 single embryos grown from morula to early yolk sac stages of development in vitro. Timing and CG measurements are centred to the day of attachment of embryos to a monolayer of marmoset fibroblasts on the base of each culture well, samples of control media in wells not containing embryos being collected at the same time. CG was not measurable during pre-attachment stages (morula-hatched blastocyst), but concentrations increased rapidly after attachment.

Table 5. Termination of pregnancy in marmoset monkeys immunized actively or passively against hCG- $\beta$ subunit (Hearn, 1976; 1979). The effect of passive immunization, with $0.5 \mathrm{ml}$ plasma from actively immunized animals showing high antibody titres, was rapid. After active immunization, no pregnancies occurred while antibody titres remained high. After passive immunization, animals became pregnant again from 2 weeks after termination

\begin{tabular}{lccc}
\hline Immunization & $\begin{array}{r}\text { Weeks pregnent } \\
\text { at immunization }\end{array}$ & $\begin{array}{c}\text { Time to } \\
\text { termination }\end{array}$ & No./total \\
\hline Active & $3-5$ & $<4$ weeks & $8 / 10$ \\
Passive & 3 & $2-6$ days & $10 / 10$ \\
\hline
\end{tabular}


Table 1. Mean interval ( $\mathrm{h} \pm \mathrm{s}$.d.) from norgestomet implant removal to standing oestrus, temperature peaks, LH peak and ovulation, and correlation coefficients $(r)$ with the time to ovulation in cycling

Holstein heifers $(n=16)$

\begin{tabular}{lcrl}
\hline Parameter & Mean & \pm s.d. & $r$ \\
\hline $\begin{array}{l}\text { Standing oestrus } \\
\text { Vaginal temperature }\end{array}$ & 30.7 & 9.8 & $0.92^{*}$ \\
$\quad$ peak & 36.4 & 9.9 & 0.51 \\
Rectal temperature & & & \\
$\quad$ peak & 36.8 & 8.6 & 0.44 \\
LH peak & 34.2 & 8.8 & $0.96^{*}$ \\
Ovulation & 60.1 & 11.4 & 1.00 \\
\hline
\end{tabular}

*Significantly correlated $(P<0.01)$.

ovulation, and the LH surge and ovulation were very strong. Although both rectal and vaginal peak temperatures were correlated with onset of standing oestrus, there was no correlation with ovulation. The single best practical parameter for basing the time of insemination was the onset of standing oestrus. The temporal relationships among standing oestrus, the LH surge and ovulation are in agreement with those reported in cows synchronized with double injections of PGF- $2 \alpha$ (Rajamahendran et al., 1989). The present study further supports the notion that young animals ovulate later in relation to oestrus and the LH surge than mature cows (Christenson et al., 1975; Schams et al., 1977; Rajamahendran et al., 1989).

Ultrasound imaging has been used effectively to monitor ovarian follicular dynamics and CL growth during different reproductive states in cattle and the measurement of these structures with a built-in caliper system has been validated (Pierson \& Ginther, 1988; Rajamahendran \& Walton, 1988). A wave-like pattern of follicular growth occurs during the oestrous cycle, 3 waves being common in heifers (Savio et al., 1988; Sirois \& Fortune, 1988). Three waves of follicular growth observed in heifers in the present study as well as the sizes of the dominant follicles, CL, timing of regression of dominant follicles and $C L$ are in agreement with the above reports.

The present study reveals that treatment of heifers with norgestomet at dioestrus (in the presence of CL) did not have any effect on the wave-like pattern of follicular growth, but, when the treatment was given at pro-oestrus (in the absence of $\mathrm{CL}$ ), the dominant follicle present was maintained for the duration of the treatment and there was no growth of medium or small follicles. These differences in follicular dynamics could be due to changes in the secretory pattern of LH. Sirois et al. (1989) also reported prolonged maintenance of an ovulatory dominant follicle with the administration of low concentrations of progesterone. This implies that the norgestomet treatment given during pro-oestrus mimics the actions of low concentrations of progesterone. In cattle, administration of subnormal concentrations of progesterone has been shown to alter LH secretory pattern compared with animals receiving normal luteal concentrations (Ireland \& Roche, 1982; Roberson et al., 1989). Roberson et al. (1989) also reported that the concentrations of oestradiol$17 \beta$ were higher and the onset of preovulatory surge was earlier in cows receiving subnormal progesterone stimulation. This, according to our observation, may be related to the presence of an ovulatory follicle at progesterone withdrawal.

Two out of 8 heifers treated at pro-oestrus ovulated in spite of norgestomet treatment. This may be due to either insertion of the implant after the LH surge or insufficient norgestomet released from the implant to inhibit the LH surge. The fact that these 2 heifers had small CL at implant removal indicates that sufficient norgestomet was released to either suppress luteotrophic support (Ottobre, 1980; Battista et al., 1984) or cause early luteal regression (Ottobre, 1980, Garrett et al., 1988). Administration of progesterone early in the cycle has been shown to reduce oestrous cycle length in cattle (Rajamahendran et al., 1981). Possible reasons for reduced fertility in cows 


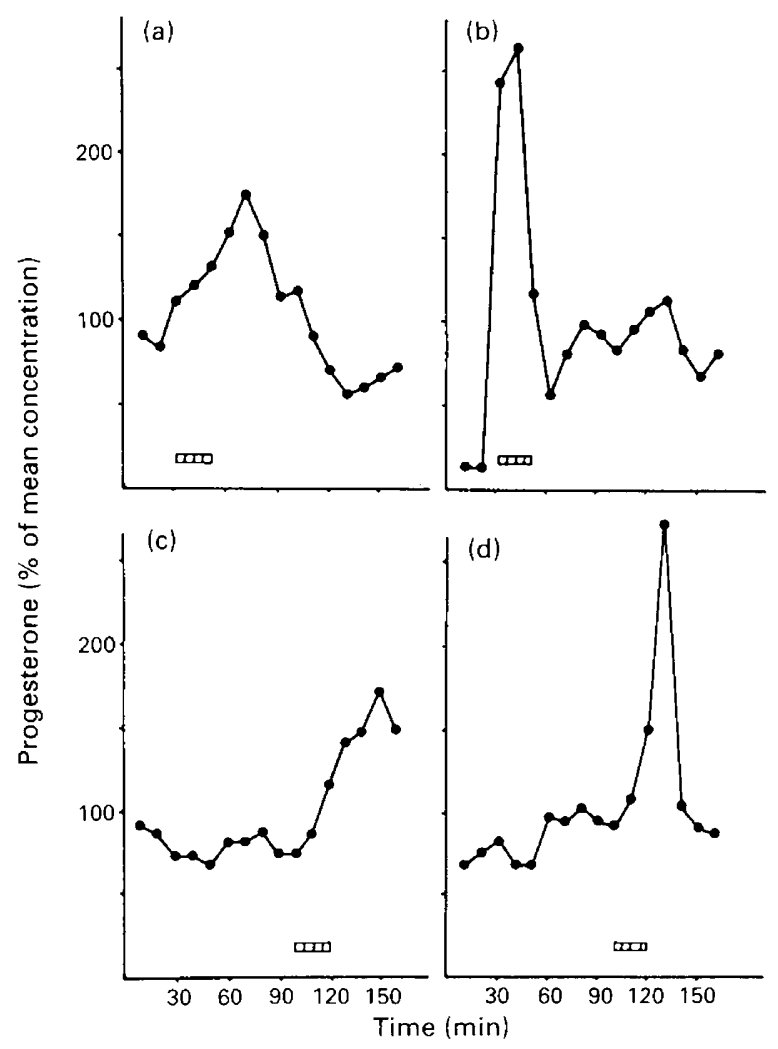

Fig. 2. Progesterone concentrations in 10-min fractions of Krebs-Ringer bicarbonate buffer before and after perfusion of $25 \mathrm{i}$.u. human chorionic gonadotrophin (hCG)/ml for $30 \mathrm{~min}$ (एIII). The hCG was perfused through the corpus luteum in the ovaries of marmosets after collection of control, preCG perfusion samples. Progesterone concentration is expressed as a percentage of the mean ([P]) during the whole sampling period. Left ovary of (a) marmoset No. $180[\mathrm{P}]=15.2 \mathrm{nmol} / 1$ and (b) marmoset No. $253,[\mathrm{P}]=46.8 \mathrm{nmol} / \mathrm{l}$; and right ovary of (c) marmoset No. $180,[\mathrm{P}]=5 \cdot 2 \mathrm{nmol} / 1$ and (d) marmoset No. $253,[\mathrm{P}]=8 \cdot 1 \mathrm{nmol} / 1$.

\section{Other luteotrophic embryo signals}

By Day 14 after ovulation, dispersed marmoset luteal cells in short-term incubation showed a significant difference in their progesterone response and control baselines between pregnant and nonpregnant animals (Fig. 5) (Webley et al., 1989). Therefore, although the mean peripherally detected concentrations of CG were not significant until Day 17, the marmoset CL is apparently responding to a luteotrophic stimulus in the conception cycle by Day 14, which is within 2 days of attachment and before there is any morphologically distinct vascular connection (Smith et al., 1987). By Day 20, CG secretion in vivo and in vitro is rising rapidly, yet luteal cells from Day-20 pregnant animals showed a lower basal production of progesterone than cells from Day-14 pregnant animals and responded to stimulation by $C G$ or prostaglandins. The mechanism of CL rescue is likely to be more complex than a simple relationship between $\mathrm{CG}$ and the luteal cell response with progesterone. In particular, the ontogeny of CG recognition, the sequential sensitivity of luteal CG receptors and the possible autocrine and paracrine interactions of progesterone itself require clarification. The simple hypothesis that $\mathrm{CG}$ alone takes over the luteotrophic prolongation of CL progesterone production is likely to be modified once the modulating effects of other hormones (e.g. 


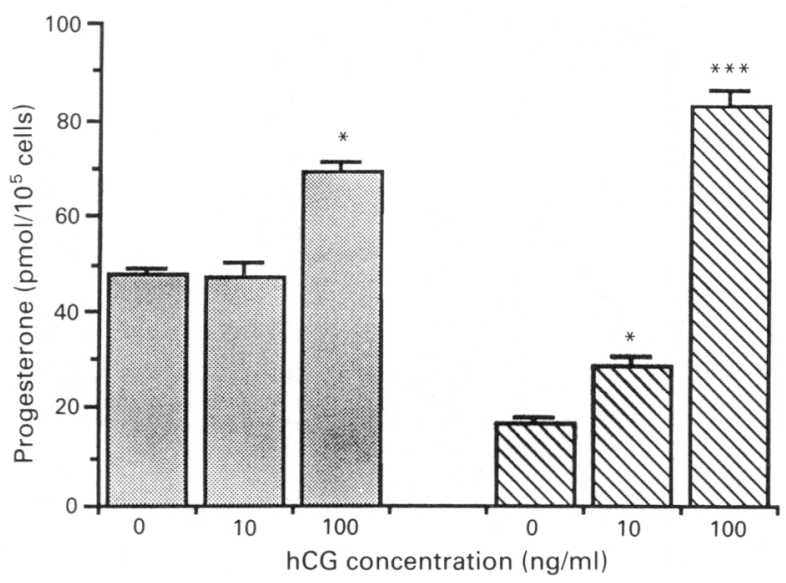

Fig. 3. Progesterone concentrations (mean \pm s.e.m. for 4 incubation replicates) produced by dispersed luteal cells from a marmoset monkey (橉) on Day 8 after ovulation and from a woman $(\mathbb{Q})$ in the midluteal phase and incubated for $2 \mathrm{~h}$ with increasing concentrations of human chorionic gonadotrophin (hCG); ${ }^{*} P<0.05,{ }^{* * *} P<0.001$.

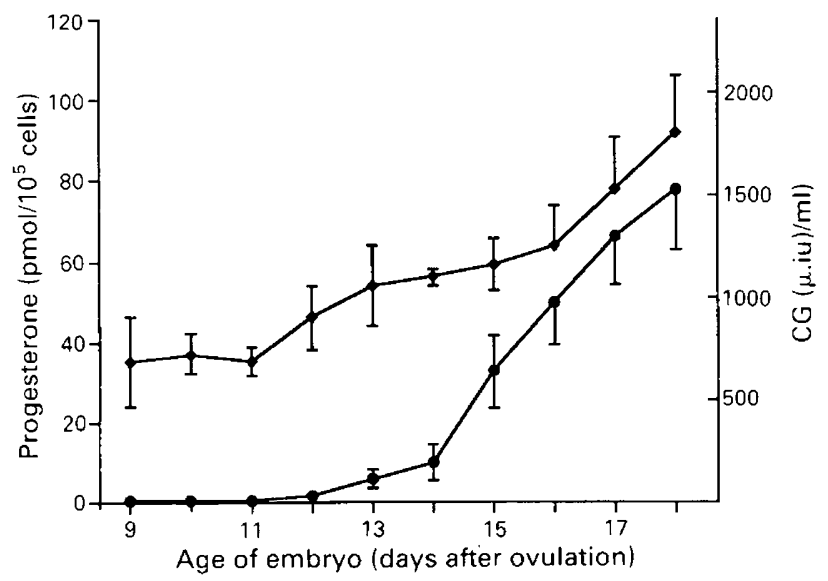

Fig. 4. Progesterone concentrations produced by marmoset luteal cells in monolayer culture and incubated for $24 \mathrm{~h}$ (after incubation for $48 \mathrm{~h}$ ) in the presence of embryo-conditioned medium pooled from 4 embryos and cultured for 10 days from Day 8 after ovulation to Day 18 . Concentrations of chorionic gonadotrophin $(\mathrm{CG})$ in the embryo-conditioned medium were measured by the mouse Leydig cell bioassay.

inhibin and relaxin) and growth factors are better understood. The sensitivity of our CG bioassay may also leave our results during the preattachment phase open to interpretation.

Webley et al. (1991) have shown that immunoreactive inhibin concentrations are higher in the peripheral circulation of marmoset monkeys by Day 9 after ovulation in conception cycles than in nonpregnant, luteal-phase controls (Fig. 6). In these studies, as previously, CG was not detected in the peripheral circulation before Day 17. Even allowing for bioactive $C G$ to be produced by the embryo at attachment on Day 12, as it is in vitro, there are 4 days when inhibin concentrations are already high, before embryo attachment. The source of this inhibin has yet to be verified, but it is known that human CL expresses mRNA for inhibin, as does the placenta (Davies et al., 1987; Petraglia et al., 1987, 1989). 


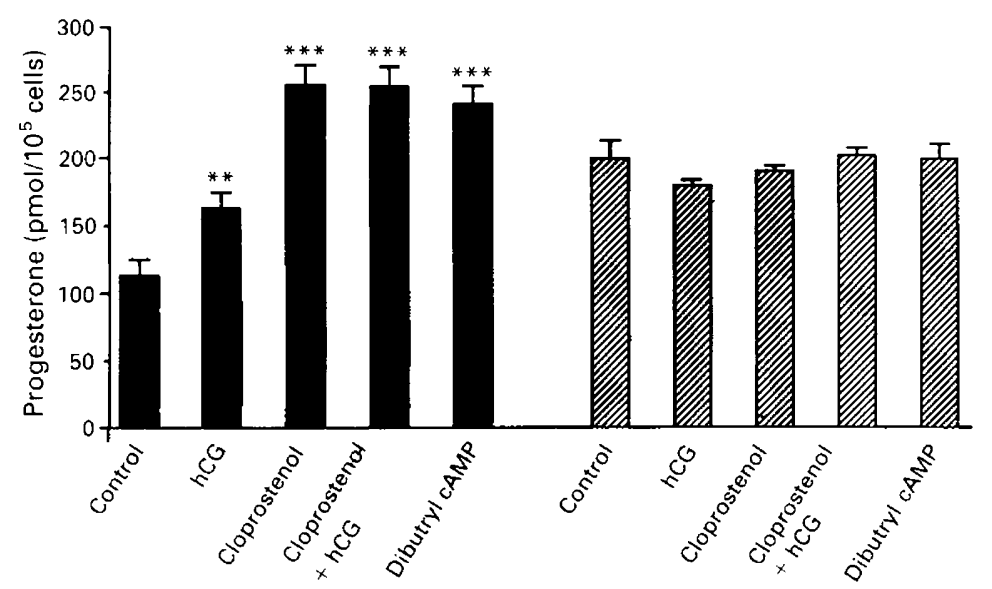

Fig. 5. Progesterone concentrations (mean \pm s.e.m. for 4 incubation replicates) produced by dispersed luteal cells from a pregnant $(\mathbb{Z})$ and a nonpregnant $(\boldsymbol{\square})$ marmoset on Day 14 after ovulation and incubated with $1000 \mathrm{ng}$ human chorionic gonadotrophin $(\mathrm{hCG}) / \mathrm{ml}, 0.5 \mu \mathrm{g}$, cloprostenol $/ \mathrm{ml}$ and $1 \mathrm{mmol}$ dibutryl cAMP $/ 1 ;{ }^{*} P<0.01,{ }^{* * *} P<0.001$.

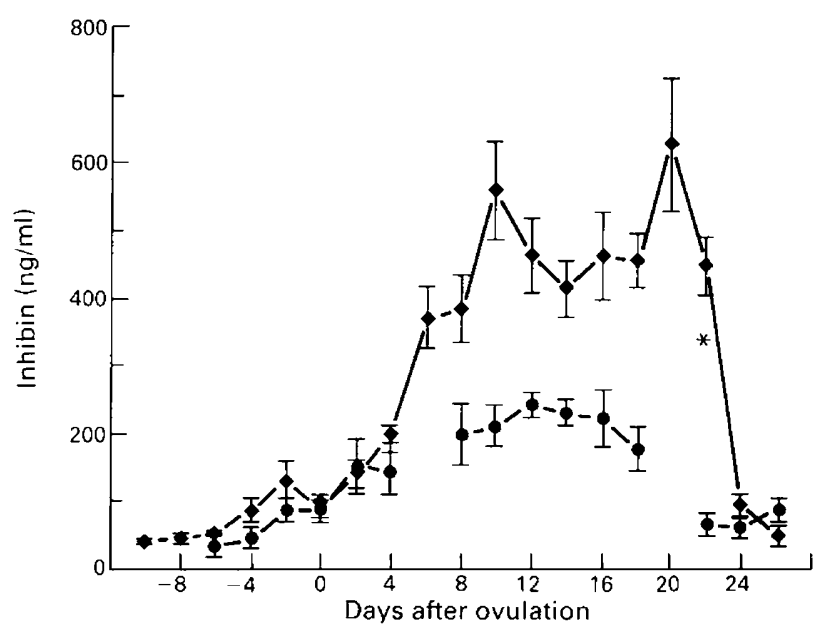

Fig. 6. Concentrations of immunoreactive inhibin (mean \pm s.e.m.) in plasma samples taken from pregnant $(\diamond)$ and nonpregnant $(\bullet)$ marmosets. ${ }^{*} P<0.05$, first time in the cycle when immunoreactive inhibin concentrations in pregnant animals were significantly higher than in nonpregnant animals. Embryo implantation commences on Day 11-12.

\section{Conclusions}

The embryonic genome in mammals studied to date, including primates, is activated before the 16-cell stage. Although CG gene transcription is apparent from these early stages in man, before cell lineage modifications are established, there is no conclusive evidence for the extraembryonic secretion of CG until the time of embryo attachment. There is increasing evidence that the presence of the embryo may be recognized through other mechanisms or signals before attachment in primates, but the identification, timing of expression and mechanisms of action of these putative signals require confirmation. The ontogeny of expression, in addition to $\mathrm{CG}$, of growth factors, 
$\mathrm{GnRH}$, adhesion proteins, steroids and many early placental proteins may have a bearing on the embryo-maternal interface. The prerequisite for further advance in our understanding of implantation in primates is the availability of sufficient, precisely timed primate embryos, early trophoblast, endometrial and luteal tissues during the peri-implantation stages of pregnancy to enable experimental studies in vivo and in vitro.

We acknowledge the assistance and advice in related studies of Drs J. K. Hodges, C. O'Neill, and P. Summers; the technical support of S. Gems and A. Given; and the animal care provided by T. Noble, D. Stula, M. Llovett and their colleagues. The work was supported by a programme grant (to J. P. Hearn) from the MRC and AFRC, with additional project grants (to J. P. Hearn and G. E. Webley) from the World Health Organisation Special Program of Research, Training and Research Development in Human Reproduction, and from Medeva plc, London, UK.

\section{References}

Anderson, T.L. \& Hodgen, G.D. (1989) Uterine receptivity in the primate. In Development of Preimplantation Embryos and Their Environment, pp. 389--399. Eds K. Yoshinaga \& T. Mori, Alan R. Liss, New York.

Atkinson, L.E., Hotchkiss, J., Fritz, G.R., Surve, A.H., Neill, J.D. \& Knobil, E. (1975) Circulating levels of steroids and chorionic gonadotropin during pregnancy in the rhesus monkey, with special attention to the rescue of the corpus luteum in early pregnancy. Biol. Reprod. 12, 335 345.

Auletta, F.J. \& Flint, A.P.F. (1988) Mechanisms controlling corpus luteum function in sheep, cow, nonhuman primates and women especially in relation to the time of luteolysis. Endocr. Rev. 9, 88-105.

Baird, D.T. (1985) Control of luteolysis. In The Luteal Phase, pp. 25-43. Ed. S. L. Jeffcoate. John Wiley \& Sons, Chichester.

Bolton, V.N., Oades, P.J. \& Johnson, M.H. (1984) The relationship between cleavage, DNA replication and gene expression in the mouse 2-cell embryo. $J$. Embryol exp. Morphol. 79, 139-163.

Bonduelle, M.-L., Dodd, R., Liebaers, I., Steirteghem, A. Van., Williamson, R., \& Akhurst, R. (1988) Chorionic gonadotrophin- $\beta$ mRNA, a trophoblast marker, is expressed in human 8-cell embryos derived from tripronucleate zygotes. Hum. Reprod. 3, 909-914.

Braude, P.R., Bolton, V. \& Moore, S. (1988) Human gene expression first occurs between the four- and eight-cell stages of preimplantation development. Nature, Lond. 332, $459-461$.

Canfield, R.E., Morgan, F.J., Kammerman, S., Bell, J.J. \& Agosto, G.M. (1971) Studies of human gonadotrophin. Recent Prog. Horm. Res. 27, 121-156.

Chambers, P.L. \& Hearn, J.P. (1979) Peripheral plasma levels of progesterone, oestradiol-17 $\beta$, oestrone, testosterone, androstenedione and chorionic gonadotrophin during pregnancy in the marmoset monkey, Callithrix jacchus. J. Reprod. Fert. 56, 23-32.

Cocchiara, R., Di Trapani, G., Azzolina, A., Albeggiani, G., Ciriminna, R., Cefalu, E., Cittadini, E. \& Geraci, D. (1987) Isolation of a histamine releasing factor from human embryo culture medium after in vitro fertilization. Hum. Reprod. 2, 341-344.

Crosby, I.M., Gandolfi, F. \& Moor, R.M. (1988) Control of protein synthesis during early cleavage of sheep embryos. J. Reprod. Fert. 82, 769-775.
Davis, S.R., Krozowski, Z., McLachlan, R.I. \& Burger, H.G. (1987) Inhibin gene expression in the human corpus luteum. J. Endocr. 115, R21-23.

Edwards, R.G. (1985) Current status of human conception in vitro. Proc. R. Soc., Lond. B 223, 417-448.

Enders, A.C. (1989) Trophoblast differentiation during the transition from trophoblastic plate to Lacunar stages of implantation in the rhesus monkey and human. Am. J. Anat. 186, 85-98.

Enders, A.C., Hendrickx, A.G. \& Schlafke, S. (1983) Implantation in the rhesus monkey: initial penetration of endometrium. Am. J. Anat. 167, 275-298.

Finn, C.A. (1986) Implantation, menstruation and inflammation. Biol. Rev. 61, 313-328.

Fishel, S.B., Edwards, R.G. \& Evans, C.J. (1984) Human chorionic gonadotrophin secreted by preimplantation embryos cultured in vitro. Science, N.Y. 223, $816-818$.

Flach, G., Johnson, M.H., Braude, P.R., Taylor, R.A.S. \& Bolton, V.N. (1982) The transition from maternal to embryonic control in the 2-cell mouse embryo. EMBO J. 1, 681-686.

Frei, R.E., Schultz, G.A. \& Church, R.B. (1989) Qualitative and quantitative changes in protein synthesis occur at the 8-16 cell stage of embryogenesis in the cow. J. Reprod. Fert. 86, 637 641.

Glasser, S.R., Julian, J., Munir, M.I. \& Soares, M.J. (1987) Biological markers during early pregnancy: trophoblastic signals of the peri-implantation period. Environ. Health Perspectives 74, 129-147.

Harper, M.J.K., Kudolo, G.B., Alecozay, A.A. \& Jones, M.A. (1989) Platelet-activating factor (PAF) and blastocyst-endometrial interactions. In Development of Preimplantation Embryos and Their Environment, pp. 305-315. Eds. K. Yoshinaga \& T. Mori. Alan R. Liss, New York.

Hay, L. \& Lopata, A. (1988) Chronic gonadotropin secretion by human embryos in vitro. J. clin. Endocr. Metab. 67, 1322-1324.

Heap, R.B., Fleet, I.R., Finn, C., Ellis, S.T., Yang, C.-B., Whyte, A. \& Brigstock, D.R. (I988) Maternal reactions affecting early embryogenesis and implantation. J. Reprod. Fert., Suppl. 36, 83-97.

Hearn, J.P. (1976) Immunization against pregnancy. Proc. R. Soc. Lond., B 195, 149-160. 
Hearn, J.P. (1979) Immunological interference with the maternal recognition of pregnancy in primates. In Maternal Recognition of Pregnancy (Ciba Foundation Symposium 62), pp. 353 375. Excerpta Medica, Amsterdam.

Hearn, J.P. (1986) The embryo-maternal dialogue during early pregnancy in primates. $J$. Reprod. Fert. 76, 809819.

Hearn, J.P. \& Summers, P.M. (1986) Experimental manipulation of embryo implantation in the marmoset monkey and exotic equids. Theriogenology $\mathbf{2 5}$, 3-11.

Hearn, J.P. \& Webley, G.E. (1987) Regulation of the corpus luteum of early pregnancy in the marmoset monkey: local interactions of the luteotrophic and luteolytic hormones in vivo and their effects on the secretion of progesterone. J. Endocr. 114, 231-239.

Hearn, J.P., Hodges, J.K. \& Gems, S. (1988a) Early secretion of chorionic gonadotrophin by marmoset embryos in vivo and in vitro. J. Endocr. 119, 249-255.

Hearn, J.P., Gidley-Baird, A.A., Hodges, J.K., Summers, P.M. \& Webley, G.E. (1988b) Embryonic signals during the peri-implantation period in primates. $J$. Reprod. Fert., Suppl. 36, 4958.

Hearn, J.P., Hendrickx, A.G., Webley, G.E. \& Binkerd, P.I. (in press) Embryonic development. In Marshall's Physiology of Reproduction 3. Ed. E. Lamming. Churchill-Livingstone, Edinburgh.

Hendrickx, A.G. \& Enders, A.C. (1980) Implantation in non-human primates. II Endocrinology. In Nonhuman Primate Models for Study of Human Reproduction, pp. 109116. Ed. T. C. Anand Kumar. Karger, Basel.

Hertig, A.T. \& Rock, J. (1945) Two human ova of the pre-villous stage having a developmental age of about seven and nine days respectively. Carnegie Contrib. Embryol. 31, 65-84.

Hodges, J.K., Henderson, C. \& Hearn, J.P. (1983) Relationship between ovarian and placental steroid production during early pregnancy in the marmoset monkey (Callithrix jacchus). J. Reprod. Fert. 69, 613-621.

Knobil, E. (1973) On the regulation of the primate corpus luteum. Biol. Reprod. 8, 246-258.

Leigh, S.E.A. \& Stewart, F. (1990) Partial cDNA sequence for the donkey chorionic gonadotrophin- $\beta$ subunit suggests evolution from an ancestral LH- $\beta$ gene. $J$. Mol. Endocr. 4, 143-150.

Lenton, E.A. \& Woodward, A.J. (1988) The endocrinology of conception cycles and implantation in women. J. Reprod. Fert. 36, 1-15.

Lenton, E.A., Osborn, J., Colman, C. \& Fothergill, D. (1988) Premenstrual pregnancy loss. Ann. N.Y. Acad. Sci. 541, 498-509.

Manes, C. (1973) The participation of the embryonic genome during early cleavage in the rabbit. Devl Biol. 32, 453-459.

Marston, J.H., Penn, R. \& Sivelle, P.C. (1977) Successful autotransfer of tubal eggs in the rhesus monkey, Macaca mulatia. J. Reprod. Fert. 49, 175-176.

Moor et al. (1966).

Moore, H.D.M., Gems, S. \& Hearn, J.P. (1985) Early implantation stages in the marmoset monkey (Callithrix jacchus). Am. J. Anat. 172, 265-278.
Morton, H., Rolfe, B., Clunie, G.J.A., Anderson, M.J. \& Morrisson, J. (1977) An early pregnancy factor detected in human serum by the rosette inhibition test. Lancet i, 394-397.

Ohlsson, R., Larsson, E., Nilsson, O., Wahlstrom, T. \& Sundstrom, P. (1989) Blastocyst implantation proceeds induction of insulin like growth factor Il gene expression in human trophoblasts. Development 106, $555-559$.

O'Neill, C. (1985) Examination of the causes of early pregnancy associated thrombocytopenia in mice. $J$. Reprod. Fert. 73, 567-577.

Petraglia, F., Sawechenko, P., Kim, A.T.W., Rivier, J. \& Vale, W. (1987) Localisation, secretion and action of inhibin in human placenta. Science, N.Y. 237, 187-189.

Petraglia, F., Vaughan, J. \& Vale, W. (1989) Inhibin and activin modulate the release of gonadotropin-releasing hormone, human chorionic gonadotropin and progesterone from cultured human placental cells. Proc. Natl Acad. Sci. USA 86, 5114-5117.

Reyes, F.I., Winter, J.S.D., Faiman, C. \& Hobson, W.C. (1975) Serial serum levels of gonadotropins, prolactin and sex steroids in the nonpregnant and pregnant chimpanzee. Endocrinology 96, 1447-1455.

Ross, G.T. (1979) Human chorionic gonadotrophin and maternal recognition of pregnancy. In Maternal Recognition of Pregnancy (Ciba Foundation Symposium 64), pp. 191-208. Excerpta Medica, Amsterdam.

Shaikh, A.A. (1978) Animals Models for Research in Human Reproduction. NIH Invited Report, Washington.

Short, R.V. (1969) Implantation and the maternal recognition of pregnancy. In Foetal Anatomy (Ciba Foundation Symposium 23), pp. 2-26. Churchill, London.

Short, R.V. (1979) When a conception fails to become a pregnancy. In Maternal Recognition of Pregnancy (Ciba Foundation Symposium 64), pp. 377-395. Excerpta Medica, Amsterdam.

Sinosich, M.J., Ferrier, A. \& Saunders, D.M. (1985) Monitoring of postimplantation embryo viability following successful in vitro fertilization and embryo transfer by measurements of placental proteins. Fert. Steril. 44, 70-74.

Smith, C.A., Moore, H.D.M. \& Hearn, J.P. (1987) The ultrastructure of early implantation in the marmoset monkey (Callithrix jacchus). Anat. Embryol. 175, $399-410$.

Stevens, V.C. (1976) Perspectives of development of a fertility control vaccine from hormonal antigens of the trophoblast. In Development of Vaccines for Fertility Regulation (World Health Organization meeting), pp. 93-110, Scriptor, Copenhagen.

Stouffer, R.L., Ottobre, J.S., Molskness, T.A. \& ZelinskjWooten, M.B. (1989) The function and regulation of the primate corpus luteum during the fertile menstrual cycle. In Development of Preimplantation Embryos and Their Environment, pp. 129-142. Eds. K. Yoshinaga \& T. Mori. Alan R. Liss, New York.

Summers, P.M., Shephard, A.M., Taylor, C.T. \& Hearn, J.P. (1987) The effects of cryopreservation and transfer on embryonic development in the common 
marmoset monkey, Callithrix jacchus. J. Reprod. Fert. 79, 241-250.

Surani, M.A., Allen, N.D., Barton, S.C., Fundele, R., Howlett, S.K., Norris, M.J. \& Reik, W. (1990) Developmental consequences of imprinting of parental chromosomes by DNA methylation. Phil. Trans. R. Soc. B 326, 313-327.

Talmadge, K., Boorstein, W.R., Vamuakopolous, N.C., Gethung, M.J. \& Fiddes, J.C. (1984) Only 3 of the $7 \mathrm{hCG}$ beta subunit genes can be expressed in the placenta. Nucleic Acids Res. 12, 8415-8436.

Talwar, G.P., Dubey, S.K., Salahuddin, M. \& Shastri, N. (1976) Kinetics of antibody response in animals injected with processed beta hCG conjugated to tetanus toxoid. Contraception 13, 153-162.

Tesarik, J. (1989) Involvement of oocyte-coded message in cell differentiation control of early human embryos. Development 105, 317-322.

Waites, G.T. \& Bell, S.C. (1989) Immunohistological localisation of human pregnancy associated endometrial $\alpha 2$-globulin ( $\alpha 2-\mathrm{PEG}$ ), a glycosylated $\beta$ lactoglobulin homologue, in the decidua and placenta during pregnancy. J. Reprod. Fert. 87, 291300.

Wang, M.W., Whyte, A., King, I., Taussig, M.J. \& Heap, R.B. (1989) Immunofluorescent localization, by use of anti-idiotypic antibody, of monoclonal antipro- gesterone antibody in the mouse uterus before implantation. J. Reprod. Fert. 86, 211-218.

Webley, G.E. \& Hearn, J.P. (1987) Local production of progesterone by the corpus luteum of the marmoset monkey in response to perfusion with chorionic gonadotrophin and melatonin in vivo. J. Endocr. 112, 449-457.

Webley, G.E., Abbott, D.H., George, L.M., Hearn, J.P. \& Mehl, H. (1989) Circadian pattern of plasma melatonin concentrations in the marmoset monkey (Callithrix jacchus). Am. J. Primatol. 17, 73-79.

Webley, G.E., Richardson, M.C., Summers, P.M., Given, A. \& Hearn, J.P. (1989) Changing responsiveness of luteal cells of the marmoset monkey (Callithrix jacchus) to luteotrophic and luteolytic agents during normal conception cycles. J. Reprod. Fert. 87, 301-310.

Webley, G.E., Knight, P.G., Given, A. \& Hodges, J.K. (1991) Increased concentrations of immunoreactive inhibin during conception cycles in the marmoset monkey: suppression with an LHRH antagonist and cloprostenol. J. Endocr. In Press.

Yoshinaga, K. \& Mori, T. (Eds) (1989) Development of Preimplantation Embryos and Their Environment. Alan R. Liss, New York. 